\title{
Frost ring distribution in Araucaria araucana trees from the xeric forests of Patagonia, Argentina
}

\author{
Distribución de anillos de heladas en árboles de Araucaria araucana en bosques xéricos \\ de la Patagonia argentina
}

\author{
Martín Ariel Hadad a*, Mariano Martín Amoroso a, Fidel Alejandro Roig Juñent a \\ *Corresponding author: a IANIGLA, CCT CONICET-Mendoza, Departamento de Dendrocronología e Historia Ambiental, Av Ruiz \\ Leal s/n, cc 330, Mendoza, Argentina, tel.: 54-261-5244050, fax: 54-261-5244001, mhadad@mendoza-conicet.gob.ar
}

\begin{abstract}
SUMMARY
Frost rings are defined as anatomically abnormal and ecophysiologically pathological structures. We studied frost injuries in tree-rings of Araucaria araucana trees growing at the northern limit of its natural distribution. We recorded 121 frost injuries at two sites in the northern xeric distribution of $A$. Araucana forests. Frost rings at both sites were primarily restricted to the middle frost ring section of the rings. These results represent the first attempt to report and describe the occurrence of these events for this species and region. These proxy records represent important indicators of extreme temperature conditions.
\end{abstract}

Key words: tree-rings, injuries, earlywood, latewood, extreme events.

\section{RESUMEN}

Las lesiones de heladas en los anillos de crecimiento de árboles son definidas como estructuras anatómicamente anómalas y ecofisiológicamente patológicas. En este trabajo se estudiaron estos anillos de heladas en árboles de Araucaria araucana creciendo al límite norte de su distribución natural. Se registraron 121 marcas de heladas para los dos sitios estudiados. En ambos sitios el mayor porcentaje de heladas se ubicaron en la mitad del anillo. Estos resultados representan un primer intento de informar y describir la ocurrencia de marcas de heladas en anillos de crecimiento para esta especie y la región. Registros de esta naturaleza representan importantes indicadores de eventos extremos en la temperatura.

Palabras clave: anillos de crecimiento, lesiones, leño temprano, leño tardío, eventos extremos.

\section{INTRODUCTION}

Extreme climatic events could have strong effects on forest ecosystems altering the state, functioning, and stability. At high latitudes, these events include frosts and long-term air temperature drops during the growing season (Hantemirov et al. 2000). Frost records can be recorded in the annual rings of tree species and are defined by Schweingruber (2007) as anatomically abnormal and ecophysiologically pathological structures resulting from frost injuries to the cambium in the xylem, with local difficulties in sap flow dynamics and normal continuity of radial and axial tracheid morphology. In general, frost rings consist of underlignified, crumpled (deformed) tracheids, collapsed cells, traumatic parenchyma cells, and abnormal tracheids (Glerum and Farrar 1966). The position of the tissue damaged by the frost within the ring is determined by the season in which the frost event occurrs, resulting in damaged rings caused by late and/or early frosts (Stöckli and Schweingruber 1996). Even when the impact of frosts on trees can be rapid or unnoticeable, frost rings have been used as markers of extreme temperature events occurring during the growing season and the construction of frostring chronologies could be used as proxies of climate variability in the forest environment (Payette et al. 2010).

Araucaria araucana (Molina) K. Koch (pehuén), an endemic species to the northern extremes of the South American temperate Subantarctic forests of Argentina and Chile (Roig and Villalba 2008), have been demonstrated to be a useful tree species for spatial and temporal reconstructions of growth variability (Mundo et al. 2012). In this work, we described the first attempt in reporting frost injuries in different positions of the Araucaria arucana treerings in the Argentine northwestern Patagonia.

\section{METHODS}

The study was conducted at two A. araucana stands of open forests growing in rocky outcrops at the forest-steppe boundary in the northwestern Patagonian foothills in the province of Neuquén, Argentina. At each stand, two increment cores per tree were taken at breast height $(1.3 \mathrm{~m})$ on a variable number of trees (table 1). Wood samples were air dried, mounted on wooden supports and sanded with pro- 
Table 1. Characteristics of the two Araucaria araucana sites in Neuquén, Argentina.

Características de los dos sitios de Araucaria araucana en Neuquén, Argentina.

\begin{tabular}{lcc}
\hline \multirow{2}{*}{ Characteristics } & \multicolumn{2}{c}{ Sites } \\
\cline { 2 - 3 } & Chenque-Pehuen & Carriel Malal \\
\hline $\begin{array}{l}\text { Number of sampled } \\
\text { trees/Number of trees }\end{array}$ & $65 / 52$ & $54 / 20$ \\
with frost rings & $1391-2007$ & $1421-2011$ \\
Chronology time span & $38^{\circ} 05^{\prime} 59,9^{\prime}$ & $38^{\circ} 55^{\prime} 36,8^{\prime}$ \\
Latitude S & $70^{\circ} 52^{\prime} 36,3^{\prime}$ & $70^{\circ} 32^{\prime} 59,8^{\prime}$ \\
Longitude W & 1,653 & 1,510 \\
Altitude (m) & 12,216 & 11,799 \\
Total rings analysed & \multicolumn{2}{c}{} \\
\hline
\end{tabular}

gressive finer sand papers in the laboratory to highlight the tree-ring annual boundary structure. Samples were visually cross-dated and ring-width series were measured on a Velmex measuring system with a precision of $0.001 \mathrm{~mm}$. The quality control of the measured tree-ring series was checked according to standard cross-comparison methods proposed by Stokes and Smiley (1968) and by statistical cross-dating procedures performed by the COFECHA computer program (Holmes 1983). Frost rings were revealed visually on the carefully smoothed surface of the samples. Frost rings were identified and the position in the ring was recorded as: early frost ring (EFR), middle frost ring (MFR) and late frost ring (LFR). The relative frequency of the frost ring ocurrence was determined. In addition, we built contingency table with the different frost positions in the two sites.

\section{RESULTS}

We recorded 121 frost injuries at the two sites, 99 in Chenque-Pehuen and 22 in Carriel Malal, representing $0.81 \%$ and $0.18 \%$ of the total number of rings analyzed at each site, respectively. Of the 65 trees sampled at Chenque-Pehuen, 52 (81.5\%) recorded at least one frost ring. Alternatively, 20 of the 54 trees sampled $(37.0 \%)$ at $\mathrm{Ca}$ rrier Malal exhibited at least one frost ring (table 1).

Frost ring dates ranged between 1401 and 1975 and only a few years showed frost injuries at both sites, such as 1916, 1941 and 1948 (table 2). There were some years

Table 2. Years of frost ring formation (*) in early frost ring (EFR), middle frost ring (MFR) and late frost ring (LFR). Double (**) represents two frost rings in the same years.

Años de formación de lesiones por heladas $\left(^{*}\right)$ en el leño temprano, mitad del leño y leño tardío del anillo. Doble $(* *)$ representa dos lesiones de heladas en el mismo año.

\begin{tabular}{|c|c|c|c|c|c|c|c|c|c|c|c|}
\hline \multicolumn{4}{|c|}{ Carrier Malal } & \multicolumn{8}{|c|}{ Chenque-Pehuen } \\
\hline Year & EFR & MFR & LFR & Year & EFR & MFR & LFR & Year & EFR & MFR & LFR \\
\hline 1703 & $*$ & - & - & 1401 & $*$ & - & - & 1863 & - & $*$ & - \\
\hline 1707 & $*$ & - & - & 1409 & - & $*$ & - & 1864 & - & $*$ & - \\
\hline 1763 & $*$ & - & - & 1424 & - & $*$ & - & 1869 & - & $*$ & - \\
\hline 1797 & - & $*$ & - & 1548 & - & * & - & 1871 & $*$ & $*$ & - \\
\hline 1846 & $*$ & - & - & 1551 & - & $*$ & - & 1875 & - & $*$ & - \\
\hline 1916 & - & $*$ & - & 1589 & - & $*$ & - & 1886 & - & $*$ & - \\
\hline 1931 & $*$ & - & - & 1624 & - & - & $*$ & 1889 & - & $*$ & - \\
\hline 1941 & $*$ & - & - & 1626 & * & - & - & 1901 & - & $*$ & - \\
\hline \multirow[t]{12}{*}{1948} & $*$ & - & - & 1627 & - & $* *$ & $* *$ & 1902 & - & $*$ & - \\
\hline & & & & 1628 & $*$ & - & - & 1908 & - & $*$ & - \\
\hline & & & & 1635 & - & $* *$ & - & 1909 & - & $*$ & - \\
\hline & & & & 1675 & - & - & $*$ & 1916 & $*$ & $*$ & - \\
\hline & & & & 1754 & - & $*$ & - & 1933 & - & $*$ & - \\
\hline & & & & 1756 & - & $*$ & - & 1937 & $*$ & - & - \\
\hline & & & & 1757 & - & $*$ & - & 1940 & $*$ & - & - \\
\hline & & & & 1766 & - & $*$ & - & 1941 & $*$ & - & - \\
\hline & & & & 1777 & - & $*$ & - & 1942 & - & $*$ & - \\
\hline & & & & 1842 & - & $*$ & $*$ & 1945 & $*$ & $*$ & - \\
\hline & & & & 1849 & - & $*$ & - & 1948 & - & - & $*$ \\
\hline & & & & 1851 & - & $*$ & - & 1975 & $*$ & - & - \\
\hline
\end{tabular}


(1842, 1871, 1916 and 1945) for which we found tree ring frost injuries in two different positions at the same site. Furthermore, we observed the formation of two xylem frost injuries within the same annual ring for the years 1627 and 1635 in Chenque-Pehuen.

Within the annual ring, frost injuries ocurred more often in the middle frost rings at both sites (table 2). For Chenque-Pehuen, $78.8 \%$ of the frost injuries occurred in the middle frost rings, $14.1 \%$ in the early frost rings and $7.1 \%$ in the late frost rings. For Carriel Malal, the proportions were $63.6 \%$ and $36.4 \%$ in the middle frost rings and early frost rings, respectively, while no injuries were found in the late frost rings. The position of the frost injury was significantly independent of the site $\left(X^{2} P=0.0037\right.$, Cramer contingency coefficient $=0.32)($ table 3$)$. The mean interval of frost events was 13.7 and 30.6 years for ChenquePehuen and Carriel Malal, respectively. The minimum interval of frost occurrence was 1 year for Chenque-Pehuen and 4 years in Carriel Malal, while the maximum interval was 124 and 70 years, respectively (table 4).

Table 3. Table Contingency indicating the frost positions within the ring and sites.

Tabla de contingencia indicando los sitios y la posición de las heladas en el anillo.

\begin{tabular}{lcc}
\hline \multirow{2}{*}{\multicolumn{1}{c}{ Position in the ring }} & \multicolumn{2}{c}{ Sites } \\
\cline { 2 - 3 } & $\begin{array}{c}\text { Chenque- } \\
\text { Pehuen }\end{array}$ & $\begin{array}{c}\text { Carriel } \\
\text { Malal }\end{array}$ \\
\hline Early frost ring & 10 & 7 \\
Middle frost ring & 31 & 2 \\
Late frost ring & 5 & 0 \\
$X^{2}$ Pearson & \multicolumn{2}{c}{0.0037} \\
Cramer contingency coefficient & \multicolumn{2}{c}{0.32} \\
\hline
\end{tabular}

Table 4. Mean, minimum and maximum intervals of frost events at the study sites.

Media, mínimo y máximo de los eventos de heladas en los sitios estudiados.

\begin{tabular}{lccc}
\hline \multicolumn{1}{c}{ Sites } & Mean & Minimum & Maximum \\
\hline Chenque-Pehuen & 13.7 & 1 & 124 \\
Carriel Malal & 30.6 & 4 & 70 \\
\hline
\end{tabular}

\section{DISCUSSION}

Reconstruction of growing-season frost activity may be used as an dendroecological tool of climate variability and may provide insights for future risks of frost damage in a warming climate and forest ecosystem (LaMarche Jr and Hirschboeck 1984, Hantemirov et al. 2004, Payette et al. 2010). In A. araucana xeric forests, frost rings occurr more often in the middle frost ring position than in other positions at both study sites. This provides evidence that early summer frosts are more frequent events at the two sites than early spring events. Similar results were found for Pinus obovata Ledeb. and Larix sibirica Ledeb. where frost injuries occurred more often in the earlywood than in the latewood (Gurskaya and Shiyatov 2006). The occurrence of frost injuries in different positions within the rings of trees for a single year (1842, 1871, 1916 and 1945), implies that frost ring damage is present in the earlywood of a tree and in the latewood of another. This could be explained on the degree of the tree ring development among individuals and the individual cold hardiness (Gurskaya and Shiyatov 2006). In addition, we observe the presence of two frost injuries in the same ring of trees during some years in Chenque-Pehuen (1627 and 1635). According to Gurskaya and Shiyatov (2002), the presence of two frost injuries provides evidence that the growing season in the corresponding years was extremely severe. Although few rings, the presence of frost records in the same years at both sites (1916, 1941 and 1948 years) suggests the presence of regional events that may affect a large forest area.

\section{CONCLUSIONS}

These results represent the first report and description of occurrence of frost events for this species and region. The differences between sites in the frequency of frost rings and frost ring positions may be related to a landscape effect: slope and geomorphology may play and important role in the frequency of frost rings. The frost ring chronologies from A. araucana developed in this study represent a reliable record for the interpretation of past extreme climatic events. Furthermore, the presence of frost rings in the same years recorded in the two chronologies indicate the capability of A. araucana to record large-scale extreme climatic events in northern Patagonia.

\section{ACKNOWLEDGMENTS}

This research was supported by the Inter-American Institute for Global Change Research (IAI-CRN2005), the Agencia Nacional de Promoción Científica y Tecnológica de Argentina (PICT-Bicentenario 2679), and the National Council for Scientific and Technical Research of Argentina (CONICET) through a doctoral fellowship granted to Martín Ariel Hadad.

\section{REFERENCES}

Glerum C, JL Farrar. 1966. Frost ring formation in the stems of some coniferous species. Canadian Journal of Botany 44: 879-886.

Gurskaya MA, SG Shiyatov. 2002. Formation of two xylem frost injuries in one annual ring in Siberian Spruce under conditions of Western Siberian Forest-Tundra. Russian Journal of Ecology 33(2): 73-79.

Gurskaya MA, SG Shiyatov. 2006. Distribution of Frost injuries 
in the wood of conifers. Russian Journal of Ecology 37(1): 7-12.

Hantemirov RM, LA Gorlanova, SG Shiyatov. 2000. Pathological tree-ring structures in Siberian juniper (Juniperus sibirica Burgsd.) and their use for reconstructing extreme climatic events. Russian Journal of Ecology 31(3): 167-173.

Hantemirov RM, LA Gorlanova, SG Shiyatov. 2004. Extreme temperature events in summer in northwest Siberia since AD 742 inferred from tree rings. Palaeogeography, $\mathrm{Pa}$ laeoclimatology, Palaeoecology 209: 155- 164.

Holmes R. 1983. Computer-assisted quality control in tree-ring dating and measurement. Tree Ring Bulletin 43: 69-75.

LaMarche Jr VC, KK Hirschboeck. 1984. Frost rings in trees as records of major volcanic eruptions. Nature 307(12): 121126.

Mundo IA, FA Roig Juñent, R Villalba, T Kitzberger, MD Barrera. 2012. Araucaria araucana tree-ring chronologies in Argentina: spatial variations and climate influences. Trees 26: 443-458.
Payette S, A Delwaide, M Simard. 2010. Frost-ring chronologies as dendroclimatic proxies of boreal environments. Geophysical Research Letters 37. L02711, DOI: 10.1029/2009GL041849.

Roig F, R Villalba. 2008. Understanding climate from Patagonian tree rings. In Rabassa J ed. Developments in Quaternary. Sciences Series. Amsterdam, The Netherlands. Elsevier. p. 411-435.

Schweingruber FH. 2007. Wood structure and environment. Berlin, Germany. Springer-Verlag. 279 p.

Stöckli V, FH Schweingruber. 1996. A common mechanism for observed similarities in xylem anomalities in response to frost drought transplantation and coppicing. In Stöckli VB ed. Tree rings as indicators of ecological processes: the influence of competition frost and water stress on tree growth size and survival. Basel, Switzerland. Dissertation Universität. p. 29-42.

Stokes M, T Smiley. 1968. An Introduction to tree-ring dating. Chicago, USA. Univ. Chicago Press. 48 p.

Recibido: 24.05.12

Aceptado: 10.10 .12 